Bülent MIRAN1

Ela ATIŞ1

Zerrin KENANOĞLU BEKTAŞ1

Ece SALALI ${ }^{1}$

Kenan ÇiFTÇi ${ }^{1}$

Ahmet BAYANER ${ }^{2}$

1 Ege Üniversitesi, Ziraat Fakültesi, Tarım Ekonomisi Bölümü , 35100, İzmir / Türkiye

2 Akdeniz Üniversitesi, İktisadi ve İdari Bilimler Fakültesi, 07058, Antalya / Türkiye

sorumlu yazar: ela.atis@ege.edu.tr

Anahtar Sözcükler:

Girdi talep fonksiyonu, pay eşitlikleri modeli, kuru üzüm, organik

Key Words:

Input demand function, share equations model, raisin, organic

\section{Türkiye'de Konvansiyonel ve Organik Çekirdeksiz Kuru Üzümde Kullanılan Girdilere Ait Talep Fonksiyonlarının Analizi: Manisa İli Örneği}

\author{
Demand Analysis for Inputs Used in Conventional and \\ Organic Raisin Productions: the Case of Manisa Province
}

Alınış (Received): 04.01.2016 Kabul tarihi (Accepted): 19.02.2016

\begin{abstract}
ÖZET
u çalışmanın amacı, organik ve konvansiyonel çekirdeksiz kuru üzüm Büretiminde kullanılan girdilere ait girdi talep fonksiyonlarını tahmin etmektir. Bu amaçla çalışmada, işgücü, kimyasal gübre, pestisit, çekigücü, bordo bulamacı+kükürt girdileri için Fiyat-Talep Esneklikleri ve Morishima Teknik İkame Esneklikleri hesaplanmıştır. Araştırmanın materyalini çekirdeksiz kuru üzüm üreten üreticilerle yüz yüze görüşülerek elde edilen yatay kesit verileri oluşturmaktadır. Manisa ili ve ilçelerinde yürütülen araştırmada, organik ve konvansiyonel yöntemlerle çekirdeksiz kuru üzüm üreten 300 çiftçi ile anket yapılmıştır. Çalışma sonunda, hem konvansiyonel hem organik kuru üzümde, fiyat değişmelerine en az duyarlı girdi işgücü olarak bulunmuştur. Konvansiyonel üzümde en duyarlı girdi pestisit, organikte ise çekigücü olarak tespit edilmiştir.
\end{abstract}

\section{GíRiş}

Dünyada yaş üzüm üretim miktarı, iklim şartlarına bağlı olarak değişmekle birlikte, yıllık 70 milyon ton civarında seyretmektedir. ABD ve Türkiye'nin yanında, önemli çekirdeksiz kuru üzüm üreticisi ülkeler; İran, Yunanistan, Şili, Avustralya, Güney Afrika ve Yunanistan'dır. Türkiye, İran, Güney Afrika Cumhuriyeti,
Şili ve Yunanistan gibi ülkeler üretimlerinin önemli bir bölümünü ihraç etme eğilimindedir ve bu ülkeler üretimlerine kıyasla çekirdeksiz kuru üzümün çok az bir kısmını iç tüketimde kullanmaktadır.

Türkiye'de 2014 yılı itibariyle yaklaşık 4.7 milyon dekar alanda 4.2 milyon ton üzüm üretilmiştir. Üretimin \%51.9'u sofralık, \%37.4'ü kurutmalık ve 
\%10.7'si ise şaraplık üzümden oluşmaktadır (TÜiK, 2015). Türkiye'nin en önemli üzüm üretim alanı Ege Bölgesidir. Ege Bölgesi, sultani çekirdeksiz üzüm çeşidinin anavatanı olmasının yanı sıra, bu çeşidin kurutmalık olarak yetiştirildiği tek bölgedir. Türkiye'nin 2011 yılı kuru üzüm ihracatı 214086 ton olup, karşılığında ise yaklaşık 507 milyon dolarlık gelir elde edilmiştir (FAO, 2014). Türkiye, dünya kuru üzüm ihracat miktarının \% 26.76'sını gerçekleştirmiş olup, en büyük ihracatçı ülke konumundadır.

Konvansiyonel olarak üretilen ve ihraç edilen çekirdeksiz kuru üzüm yanında, özellikle gelişmiş ülkelerde refah ve bilinçlenme düzeyindeki artışla, diğer organik ürünlerde olduğu gibi organik çekirdeksiz kuru üzüm talebi de artmıştır. Teknolojik gelişmeyle birlikte, birim alandan yüksek verim almayı hedefleyen üretim anlayışı, aynı zamanda ekosistemi olumsuz etkileyerek bazı çevre sorunlarının ortaya çıkmasına neden olmuştur. Tarımsal üretimden kaynaklanan bu sorunlar ile toplumda çevre sorunları ve gıda güvenliği konusunda duyarlılığın artması organik tarım gibi alternatif üretim yöntemlerinin gündeme gelmesine neden olmuştur. Türkiye'de organik olarak üretimi yapılan en önemli tarımsal ürünler arasında yer alan çekirdeksiz kuru üzüm,19841985 yıllarında kuru incir ve kuru kayısı ile birlikte, Türkiye'de ilk organik tarım uygulamalarının başladığı ürün olmuştur. Türkiye'de, 2012 yılında organik üzüm üretimi 20540.22 ton olarak gerçekleşmiş olup bunun $\%$ 63.17'si kuru üzümdür. Manisa ili, Türkiye organik üzüm üretiminin \% 62.20'sini, organik kuru üzüm üretiminin ise \% 92.65'ini karşılamaktadır (Manisa IGTHM, 2014).

Tarımsal ürünlerin fiyatlarındaki belirsizliklerden dolayı meydana gelen dalgalanmalar, üreticinin gelirlerinde yıllar itibariyle dengesizliğe yolaçmakta ve bu durum dışsatımı da etkilemektedir. Ürün fiyatları kadar tarımsal girdi fiyatları da üretici kararlarında önemli rol oynamaktadır. Girdi fiyatlarına yönelik uygulanacak politikalar üreticilerin gelirlerindeki istikrarsızlığı önlemede önemli bir araç olmasının yanısıra üreticilerin girdi kullanım düzeyini ve üretim maliyetlerini etkilemektedir. Türkiye'de kimyasal gübre ve hammadde büyük oranda yurt dışına bağımlıdır. Doğal kaynak yokluğu, bu alanlarda patent olmaması ve yeterince yerli yatırım bulunmaması en önemli nedendir. Dışardan temin edilen gübre ve ilaç gibi girdiler çoğunlukla petrol fiyatlarına bağlı olarak değişmektedir (Bayaner, 2013).

Tarımsal girdi fiyatlarındaki artışlar ve uygulanan girdi politikaları üreticilerin üretim desenine karar vermesini etkileyen önemli bir unsurdur. Türkiye'de bitkisel üretime yönelik olarak mazot ve gübre desteği, yurtiçi sertifikalı tohum kullanım desteği gibi tarımsal girdi destekleri verilmektedir. Girdi fiyatlarına dayalı politikaların uygulanmasında üreticilerin $o$ girdinin kullanımında yapabileceği muhtemel değişiklikleri ya da o girdinin yerine hangi girdileri ne ölçüde ikame edebileceğini önceden bilmek, politikaların başarısı için gereklidir (Miran ve ark., 2002). Bu çalışmanın amacı; organik ve konvansiyonel kuru üzüm üretiminde kullanılan girdilere ait girdi talep fonksiyonlarını tahmin etmektir. Bu çerçevede çalışmada, işgücü, kimyasal gübre, pestisit, çekigücü ve bordo bulamacı+kükürt girdileri için Fiyat-Talep Esneklikleri ve Morishima Teknik İkame Esneklikleri hesaplanmıştır. Araştırmanın materyalini çekirdeksiz kuru üzüm üreten üreticilerle yüz yüze görüşülerek elde edilen yatay kesit verileri oluşturmaktadır.

\section{MATERYAL ve YÖNTEM}

Çalışmada yatay kesit verilerinden yararlanılmıştır. Türkiye'den ihraç edilen çekirdeksiz kuru üzümün \%75-80'ini karşılayan ve organik tarım faaliyetlerinde de Türkiye'nin öncelikli illerinden birisini oluşturan Manisa iline bağlı Merkez, Salihli ve Turgutlu ilçeleri araştırma kapsamına alınmıştır. Araştırmada görüşülecek çiftçi sayısının belirlenmesinde, seçilmiş ilçeler bazında ÇKS'ye kayıtlı kurutmalık üzüm üreten üretici sayıları konvansiyonel bağcılık yapan işletmeler için anakitleyi oluşturmuştur. Ayrıca, OTBiS verilerine göre araştırma kapsamındaki ilçelere ait, geçiş süreci de dahil olmak üzere organik bağcılık yapan çiftçi sayıları da organik bağcılık yapan işletmeler için anakitle olarak kabul edilmiştir. Araştırmada görüşülen çiftçi sayısının belirlenmesinde oransal örnek hacmi formülünden yararlanılmıştır (Newbold, 1995). Örnek hacmi, \%99.0 güven aralığı ve \%10.0 hata payı kullanılarak hesaplanmıştır. Buna göre belirlenen 300 üreticinin 155'i konvansiyonel, 140'ו organik, beşi ise hem konvansiyonel hem de organik olarak çekirdeksiz kuru üzüm yetiştirmektedir. Hem konvansiyonel hem de organik ürün üreten 5 işletme hem konvansiyonel, hem de organik üzüm işletmelerine ait analizlerde yer almıştır.

Organik ve konvansiyonel çekirdeksiz kuru üzüm üretiminde kullanılan girdilere ait girdi talep fonksiyonlarının elde edilmesinde Pay Eşitlikleri Modelinden yararlanılmıştır. Organik ve konvansiyonel olarak üretilen kuru üzüm için dörder girdiye ilişkin girdi talep fonksiyonları tahmin edilmiştir. Konvansiyonel işletmelerde; işgücü, 
kimyasal gübre, çekigücü, pestisit, organik işletmelerde; işgücü, organik gübre, çekigücü, bordo+kükürt modellerde kullanılmıştır. Bu girdilerin dışındaki diğer girdilerin fiyatları veya fiyat indeksleri oluşturulamadığı için girdi talep modeline dahil edilmemiştir. Eldeki maliyet bilgilerinin tek bir çıktıya (kuru üzüm) ait olması ve ekonometrik tahmininin kolay olması nedeniyle kuru üzüm üretiminde girdi talebini belirlemek için Translog maliyet fonksiyonundan yararlanılmış̧ır. Kuru üzüm için tahmin edilen translog maliyet fonksiyonu, Denklem 1 'de verilmiştir.

(Denklem 1)

$$
\begin{aligned}
& \ln (m)=\alpha_{0}+\sum_{i} \alpha_{i} \ln \left(w_{i}\right)+\frac{1}{2} \sum_{i} \sum_{j} \gamma_{i j} \ln \left(w_{i}\right) \ln \left(w_{j}\right)+\beta_{0} \ln (Q)+ \\
& \beta_{1}(\ln Q)^{2}+\sum_{j} \eta_{j} \ln (Q) \ln \left(w_{j}\right)+\delta D+\sum_{j} \pi_{j} \ln \left(w_{j}\right) D+\varphi_{3} \ln (Q)(D)
\end{aligned}
$$

m: Birim üretim maliyeti (1 kg kuru üzüm üretmek için yapılan masraf)

w: Girdi fiyatları vektörü

Q: Çıktı miktarı (Dekara kuru üzüm üretimi)

D: Kukla değişken (Manisa merkez için 1, diğerleri 0).

Bu eşitlik, gerçek maliyet fonksiyonuna lokal bir yaklaşımdır. Bu nedenle, gerçek maliyet fonksiyonunda aranan iç bükeylik (concavity) özelliği gözardı edilebilir (Chambers, 1988). Ancak Translog fonksiyonun, gerçek fonksiyona doğru bir yaklaşım sağlayabilmesi için, iç bükeylik göstermesi gerekir. Fonksiyonun bu şartı sağlayıp sağlamadığı, AllenUzawa esneklik matrisinin $(\mathrm{j} x \mathrm{j}$ ) özdeğerleri (eigen value) yardımıyla belirlenmiştir. Özdeğerlerin her bir gözlem için sıfır veya negatif olması gerekmektedir. Gözlemlerden birinin iç bükeylik koşulunu ihlal etmesi, tanımlanan translog maliyet fonksiyonunun gerçek maliyet fonksiyonunu temsil etme gücünü tartışmalı hale getirebilmektedir.

Maliyetin en küçüklenebilmesi için, maliyet fonksiyonunun monotonik olması istenir. Diğer bir ifadeyle, üretim arttığında, girdi ikame oranlarının değişmeden kalması arzulanır. Bir maliyet fonksiyonunun monotonik olabilmesi için, girdi paylarının tamamının her gözlem için pozitif değere sahip olması gerekir (Fuller ve ark., 1999; Şener ve Koç 1999).

Denklem 2'de tanımlanan translog maliyet fonksiyonuna Shephard ön kuramı ${ }^{1}$ uygulandığında, maliyet fonksiyonu pay eşitliklerine bağlı olarak elde edilir (2). Bu eşitlik mikro ekonomik teorinin kısıtlarıyla uyumlu olarak tahmin edilebilir. Yanısıra, ekonometrik tahmini de kolaydır.

(Denklem 2) $s_{i}=\alpha_{i}+\sum_{j} \gamma_{i j} \ln \left(w_{j}\right)+\beta_{i} \ln (Q)+\delta_{i}(D)$

Denklem 2'de tanımlanan girdi maliyet fonksiyonu girdi fiyatlarına göre sıfırıncı dereceden homojendir. Diğer bir ifadeyle, kullanılan girdilerin fiyatları aynı oranda artırıldığında, maliyet payları değişmemektedir. Ayrica Young teoremine göre çapraz fiyat esnekliklerinin simetrik olması, maliyet payları toplamının ise 1'e eşit olması gerekir (adding-up) (Denklem 3 ve Denklem 4). Maliyet fonksiyonu tahmin edilirken, bu özellikler kısıtlamalar olarak modele konulmuştur.

$$
\text { (Denklem 3) } \sum_{i} \alpha_{i}=1 ; \gamma_{i j}=\gamma_{j i} ; v e \sum_{i} \gamma_{i j}=\sum_{i} \beta_{i}=\sum_{i} \delta_{i k}=0
$$

Model tahmin edildikten sonra aşağıdaki formüller kullanılarak esneklikler hesaplanmıştır:

\section{(Denklem 4)}

$$
\begin{aligned}
& \varepsilon_{i i}=\gamma_{i i} / s_{i}+s_{i}-1 \\
& \varepsilon_{i j}=\gamma_{i j} / s_{i}+s_{j}
\end{aligned}
$$

Pay eşitliklerine bağı ılarak tanımlanan modelden (Denklem 2), Allen ve Morishima ikame esneklikleri hesaplanmıştır. Gübre ile işgücü arasındaki Allen kısmi ikame esnekliği $\left(\sigma_{i j}\right)$, gübre-işgücü çapraz fiyat esnekliğinin işgücü maliyet payına $\left(S_{j}\right)$ bölünmesiyle elde edilmiştir (Binswanger, 1974; Akçay ve Esengün, 2000). Herhangi iki girdinin fiyat oranlarındaki değişmeye bağlı olarak bu girdilerin kullanım oranlarındaki değişmeyi ölçmek için Morishima girdi ikame esneklikleri hesaplanmıştır (Huang, 1991). Morishima girdi ikame esnekliğinin hesaplanmasında aşağıdaki formül kullanıımıştır (Chambers, 1988).

$$
\text { (Denklem 5) } \quad \sigma_{i j}^{M}=\varepsilon_{i j}-\varepsilon_{i j}
$$

Denklem 2'de tanımlanmış olan faktör talep modelinin tahminlenmesi görünüşte ilgisiz regresyon(seemingly unrelated regression $=$ SUR), maksimum likelihood (ML )veya üç aşamalı en küçük kareler (3SLS) yöntemleriyle yapılabilmektedir.

\footnotetext{
${ }^{1}$ Shephard's Lemma : $\frac{\partial c}{\partial P_{i}}=y_{i}$
} 
Bu çalışmada SUR kullanılmıştır. Sistemin çözüm verebilmesi için eşitliklerden biri tahminin dışında bırakılmıştır. Hangi eşitlik model dışında tutulursa tutulsun tahmin sonuçları değişmeyeceğinden, dışarıda kalan eşitliğin parametreleri toplam kısıtından yararlanarak hesaplanmıştır. Konvansiyonel kuru üzüm için tahmin edilen translog girdi talep modelinde homojenlik kısıtını sağlayabilmek için işgücü, gübre ve çekigücü fiyatları, pestisit fiyatı ile, organik kuru üzüm için tahmin edilen translog girdi talep modelinde ise bordo bulamacı+kükürt fiyatıyla normalleştirilmiştir.

\section{ARAŞTIRMA BULGULARI}

\section{Üreticilerin ve işletmelerin özellikleri}

Konvansiyonel kuru üzüm işletmelerinde üreticilerin yaş ortalaması yaklaşık 49 yıl, eğitim süresi 6.91 yıl, tarımdaki deneyim süresi yaklaşık 29 yıldır. Konvansiyonel işletmelerin ortalama 24.31 yıldan beri konvansiyonel çekirdeksiz kuru üzüm yetiştirdikleri saptanmıştır. Organik çekirdeksiz kuru üzüm üreticilerinin ise yaş ortalaması 51, eğitim süresi yaklaşık $6 \mathrm{yıl,} \mathrm{tarımdaki} \mathrm{deneyim} \mathrm{süresi} 31 \mathrm{yıl}$, çekirdeksiz kuru üzüm üretiminde deneyim süresi yaklaşık 28 yıldır.

Konvansiyonel kuru üzüm işletmelerinde ortalama arazi genişliği 107.62 dekar, ortalama parsel sayısı 6.23 adet, ortalama bağ arazisi 50.20 dekar, bağ arazisi ortalama parsel sayısı 4.15 olarak bulunmuştur. Organik çekirdeksiz kuru üzüm üretimi yapan işletmelerde arazi genişliği 105.63 dekar, ortalama parsel sayısı 7.32, bağ arazisi parsel sayısı 3.59 adet, bağ arazisi genişliği 42.33 dekardır. Konvansiyonel işletmelerde toplam işletme arazisinin $\% 46.65^{\prime} \mathbf{i}$, organik işletmelerde \% 40.07'si bağ arazisine ayrılmıştır.

Konvansiyonel kuru üzüm üretim dalının ortalama dekara toplam değişken masrafı 558.40 TL/dekar, organik kuru üzüm üretim dalının ise değişken masrafı 460.86 TL/dekardır. Araştırma kapsamına alınan işletmelerde organik kuru üzüm üretim dalının değişken masrafı \%17.46 oranında konvansiyonel kuru üzümün değişken masrafına göre daha düşük bulunmuştur. Konvansiyonel kuru üzümün değişken masrafları içinde en yüksek payı \%29.33 ile geçici işgücü masrafları almaktadır. Bu masrafları sırasıyla \%20.45 ile çekigücü, \%19.09 ile gübre, \%16.69 ile ilaç, \%7.55 ile materyal, \%6.89 sulama masrafları izlemektedir. Organik çekirdeksiz kuru üzümün değişken masrafları içinde en yüksek payı \%36.90 ile geçici işgücü masrafları almaktadır. Bu masrafları sırasıyla \% 25.36 ile çekigücü, $\% 13.50$ ile gübre, $\% 10.74$ ile ilaç, \%6.78 ile sulama, \%6.72 ile materyal masrafları izlemektedir. Konvansiyonel kuru üzüm üretim dalının brüt üretim değeri 1561.75 TL/daa, brüt marjı $1003.35 \mathrm{TL} /$ daa, organik çekirdeksiz kuru üzüm üretim dalının ise brüt üretim değeri ortalama 1378.51 TL/daa, brüt marjı 917.66 TL/dekar olarak bulunmuştur.

Konvansiyonel ve organik kuru üzümde girdi talep modeli tahmin sonuçları

Konvansiyonel ve organik kuru üzüm için tahmin edilen girdi talep fonksiyonları Çizelge 1 'de ve Çizelge 2'de verilmiştir.

\begin{tabular}{|c|c|c|c|c|}
\hline \multirow{2}{*}{ Bağımsız Değişken } & \multicolumn{4}{|c|}{ Bağımlı Değişken: Maliyet Payları } \\
\hline & İşgücü & Gübre & Çekigücü & Pestisit $^{b}$ \\
\hline \multirow{2}{*}{ Sabit Terim } & 0.0656430 & $0.92958^{* * *}$ & 0.0284630 & \\
\hline & $(0.54204)$ & $(7.0167)$ & $(0.60668)$ & -1.023686 \\
\hline \multirow{2}{*}{ Ln (Kuru Üzüm Üretim Miktarı) } & $0.0433260^{* * *}$ & $-0.0606190^{* * *}$ & 0.0067717 & \\
\hline & (3.2662) & $(-4.1764)$ & $(1.3215)$ & 0.01052 \\
\hline \multirow{2}{*}{ Ln (İşgücü Fiyatı / İlaç Fiyatı) } & $0.2724^{* * *}$ & $-0.0029^{* * *}$ & $-0.2709^{* * *}$ & \\
\hline & $(7.2597)$ & $(-2.2798)$ & $(-7.2297)$ & 0.00137 \\
\hline \multirow{2}{*}{ Ln (Gübre Fiyatı / İlaç Fiyatı) } & $-0.0029 * *$ & $0.0037^{* * *}$ & $-0.9^{*}$ & \\
\hline & $-2.2798)$ & $(2.7078$ & $(-1.8555)$ & 0.06 \\
\hline \multirow{2}{*}{ Ln (Çekigücü / İlaç Fiyatı) } & $-0.2709^{* * *}$ & $-0.9^{*}$ & $0.2725^{* * *}$ & \\
\hline & $(-7.2297)$ & $(-1.8555)$ & $(7.2765)$ & -0.69 \\
\hline \multirow{2}{*}{ Kukla Değişken } & 0.0051880 & 0.0115280 & 0.0061654 & \\
\hline & $(0.18126)$ & $(0.36923)$ & $(0.55612)$ & -0.02288140 \\
\hline $\mathrm{R}^{2}$ & 0.1546 & 0.1451 & 0.2599 & \\
\hline Maliyetteki payı & 0.48 & 0.38 & 0.07 & 0.06 \\
\hline
\end{tabular}


Çizelge 2: Organik Kuru Üzüm Girdi Talep Modeli Ekonometrik Tahmin Sonuçları (SUR Tahmini) Table 2: Organic Raisin Input Demand Model Econometric Estimation Results (SUR Estimation)

\begin{tabular}{|c|c|c|c|c|}
\hline \multirow[b]{2}{*}{ Bağımsız Değişken } & \multicolumn{4}{|c|}{ Bağımlı Değişken: Maliyet Payları } \\
\hline & İşgücü & Organik Gübre & Çekigücü & $\begin{array}{l}\text { Bordo-Bulamacı } \\
\text { Kükürt }^{\mathrm{b}}\end{array}$ \\
\hline Sabit Terim & $\begin{array}{l}0.159380 \\
(0.84828)\end{array}$ & $\begin{array}{r}0.516630^{* * * *}(2.947200)\end{array}$ & $\begin{array}{r}0.151550^{* * * *} \\
(2.608900)\end{array}$ & -6.404380 \\
\hline Ln (Kuru Üzüm Üretim Miktarı) & $\begin{array}{r}0.033246 \\
(1.595500)\end{array}$ & $\begin{array}{r}-0.017000 \\
(-0.874410)\end{array}$ & $\begin{array}{r}-0.004728 \\
(-0.735150)\end{array}$ & 0.014060 \\
\hline Ln (İşgücü Fiyatı / Bordo-kükürt Fiyatı) & $\begin{array}{r}0.000282^{* * * *} \\
(8.715700)\end{array}$ & $\begin{array}{l}-0.000004^{*} \\
(-1.940800)\end{array}$ & $\begin{array}{r}-0.000279 * * * \\
(-8.621100)\end{array}$ & 1.846200 \\
\hline Ln (Organik Gübre Fiyatı / Bordo-kükürt Fiyatı) & $\begin{array}{l}-0.000004^{*} \\
(-1.940800)\end{array}$ & $\begin{array}{l}0.000004^{*} \\
(1.914600)\end{array}$ & $\begin{array}{r}0.000000 \\
(-0.076433)\end{array}$ & 0.102633 \\
\hline Ln (Çekigücü / Bordo-kükürt Fiyatı) & $\begin{array}{r}-0.000279 * * * \\
(-8.621100)\end{array}$ & $\begin{array}{r}0.000000 \\
(-0.076433)\end{array}$ & $\begin{array}{r}0.000280 \\
(8.618200)\end{array}$ & 0.079333 \\
\hline Kukla Değişken & $\begin{array}{r}-0.000847 \\
(-0.021080)\end{array}$ & $\begin{array}{r}0.021746 \\
(0.579860)\end{array}$ & $\begin{array}{r}-0.015822 \\
(-1.266600)\end{array}$ & 0.707820 \\
\hline $\mathrm{R}^{2}$ & 0.06 & 0.1451 & 0.2599 & \\
\hline Maliyetteki payı & 0.51 & 0.38 & 0.05 & 0.06 \\
\hline
\end{tabular}

- Konvansiyonel kuru üzüm girdi talep modelinde tahmin edilen 18 katsayıdan 12 'si, organik kuru üzüm talep modelinde ise $8^{\prime} i$ ( $\alpha=0.10$ düzeyinde) anlamlıdır.

- Gerek konvansiyonel gerekse organik kuru üzüme ait çapraz fiyat matrisleri incelendiğinde, simetri kısıtının sağlandığı görülebilir.

- Zirai ilaç ve bordo bulamacı+kükürt maliyet payı eşitliklerinin parametreleri, modeller tahmin edildikten sonra toplam kısıt eşitliklerinden hesaplanmıştır.

- Diğer koşullar sabitken, maliyet fonksiyonu, kabul edilebilir sınırlarda içbükeydir. Üretimde kullanılan girdilerin fiyatları veya girdilerden en az birinin fiyatı artıı̆ında, birim maliyetin artması gerekir. Kuru üzüm için tanımlanan translog maliyet fonksiyonunun bu şartı sağlaması, maliyet eğrisinin içbükey (concav) veya lokal içbükey olmasını gerektirir².

- Fonksiyonlar monotoniktir3.

Kuru üzüm tarımında girdi taleplerinin, girdi fiyatlarındaki değişmelere gösterdiği tepkiyi oransal olarak ölçen esneklikler Çizelge 3 ve 4'de verilmiştir.
Girdilerin kendi fiyat esneklikleri, ana köşegende bulunmaktadır. Tüm girdiler için talebin fiyat esneklikleri beklendiği gibi negatif bulunmuştur. Konvansiyonel kuru üzümde işgücünün fiyat esnekliği -0.516 , gübrenin -0.617 , çekigücünün -0.922 ve pestisitin -0.941olarak tahmin edilmiştir. Fiyat değişmelerine en duyarlı girdi pestisit; en az duyarlı girdi ise işgücüdür. Buna göre pestisit fiyatlarındaki $\% 10^{\prime}$ luk artış, pestisit talebini \%9.4 azaltırken, işgücü fiyatlarındaki \%10 artı̧̧ işgücü talebini \%5.16 azaltmaktadır. Pestisitin fiyat duyarlıı̆ının yüksek olması, pestisit fiyatlarının farklı politika uygulamalarıyla yüksek tutularak çiftçilerin organik kuru üzüm yetiştirmeye teşvik edilmesinin mümkün olabileceğini göstermektedir. Organik tarımda işgücü kullanımının daha fazla olmasının getireceği işgücü talebi, işgücü ücretlerini arttıracaktır. Ancak kuru üzümde işgücü talebinin esnekliğinin nispeten düşük olması, çiftçilerin organik kuru üzüme geçişlerini önemli ölçüde engellemeyecektir.

Organik kuru üzümde işgücünün fiyat esnekliği -0.48951 , gübrenin -0.61775 , çekigücünün --0.94865 ve bordo bulamacı+kükürtün -0.93735 olarak tahmin edilmiştir. Yine organik kuru üzümde çiftçiler en az

\footnotetext{
${ }^{2}$ Talep sisteminin bu şartı yerine getirebilmesi için, Allen ikame esneklikleri özdeğer vektöründe pozitif değer bulunmaması beklenir. Tahmin edilen modeldeki Allen kısmi ikame esnekliklerinin özdeğerlerinden hemen hemen tamamının negatif olduğu tespit edilmiştir. içbükeylik özelliği düşük oranda ihlal ediliyorsa, kabul edilebilir sınırlarda (Laure ve ark., 1996) olduğu varsayılmaktadır.

${ }^{3}$ Maliyet fonksiyonunun monotonik olabilmesi için tahmin edilen maliyet paylarının her bir gözlem için pozitif olması istenir. Diğer bir ifadeyle üretimin bir birim artması için üretimde kullanılan girdilerin de aynı oranda artması gerekir. Tahmin edilen maliyet paylarının tamamı için pozitif değerler elde edilmiştir. Bu nedenle tahmin edilen maliyet fonksiyonu monotonik olarak kabul edilmiştir.
} 
işgücü fiyatlarındaki değişmeye duyarlılık değişmeye karşı göstermektedir. Bu durum, çiftçilerin göstermektedir. Bunun nedeni, organik üretimin organik üretimde alternatif enerji kaynakları ile toprak işgücü yoğunluklu bir üretim tekniği olmasıdır. işleme yöntemlerine yönlendirilmesinin mümkün Çiftçiler en fazla duyarlılığı çekigücü fiyatlarındaki olabileceği şeklinde yorumlanabilir.

\begin{tabular}{|c|c|c|c|c|}
\hline \multirow[b]{2}{*}{ Girdi } & \multicolumn{4}{|c|}{ Fiyat-Talep Esneklikleri } \\
\hline & İşgücü & Gübre & Çekigücü & Pestisit \\
\hline İşgücü & -0.516 & 0.383 & 0.074 & 0.059 \\
\hline Gübre & 0.483 & -0.617 & 0.075 & 0.059 \\
\hline Çekigücü & 0.479 & 0.383 & -0.922 & 0.059 \\
\hline \multirow[t]{2}{*}{ Pestisit } & 0.483 & 0.383 & 0.075 & -0.941 \\
\hline & \multicolumn{4}{|c|}{ Morishima Teknik İkame Esneklikleri } \\
\hline İ̇sücü & & 0.900 & 0.591 & 0.575 \\
\hline Gübre & 1.100 & & 0.691 & 0.676 \\
\hline Çekigücü & 1.401 & 1.305 & & 0.981 \\
\hline Pestisit & 1.424 & 1.324 & 1.016 & \\
\hline
\end{tabular}

\begin{tabular}{|c|c|c|c|c|}
\hline \multirow[b]{2}{*}{ Girdi } & \multicolumn{4}{|c|}{ Fiyat Esneklikleri } \\
\hline & İşgücü & Gübre & Çekigücü & $\begin{array}{c}\text { Bordo Bulamacı ve } \\
\text { Kükürt }\end{array}$ \\
\hline İşgücü & -0.48951 & 0.38223 & 0.04461 & 0.06266 \\
\hline Organik gübre & 0.50993 & -0.61775 & 0.04516 & 0.06266 \\
\hline Çekigücü & 0.50377 & 0.38224 & -0.94865 & 0.06264 \\
\hline BordoBulamacı+Kükürt & 0.50996 & 0.38224 & 0.04515 & -0.93735 \\
\hline \multicolumn{5}{|c|}{ Morishima Teknik İkame Esneklikleri } \\
\hline İşgücü & & 0.87174 & 0.53412 & 0.55217 \\
\hline Organik gübre & 1.12768 & & 0.66291 & 0.68041 \\
\hline Çekigücü & 1.45242 & 1.33089 & & 1.01129 \\
\hline BordoBulamacı+Kükürt & 1.44731 & 1.31960 & 0.98250 & \\
\hline
\end{tabular}

Erzurum yöresinde yapılan bir araştırmada gruplara göre değişmekle birlikte; makine sahibi olan (I. grup) işletmelerde işgücü esnekliği buğdayda -0.743 , arpada -0.645, çavdarda -1.678; makine sahibi olmayan (II. grup) işletmelerde işgücü esnekliği buğdayda -0.846 , arpada -0.537, çavdarda -1.465 bulunmuştur. Gübre esnekliği ise I. gruptaki işletmeler için buğdayda -0.704 arpada -0.339, çavdarda -0.010; Il. gruptaki işletmeler için buğdayda -0.545 , arpada 0.461, çavdarda -0.355 olarak bulunmuştur (Kumbasaroğlu ve Dağdemir, 2010). Miran ve ark. (2002) tarafindan yapılan araştırmada ise; kuru üzüm girdi talep esneklikleri pamuk için tahmin edilen esnekliklerden oldukça yüksek bulunmuştur. Örneğin pamukta işgücü esnekliği -0.165 , çekigücü esnekliği 0.451 , gübre esnekliği 0.525 , pestisit esnekliği ise -0.237 'dir. Kuru üzüm gübre ve pestisit esnekliklerinin daha yüksek olması, çiftçilerin pamuğa göre organik tarıma geçme intimallerinin daha yüksek olduğunu göstermektedir. Ancak, bu noktada, bir yandan organik tarıma yönelik desteklere yer verirken diğer yandan tarımsal destekler arasında konvansiyonel ürünlere verilen gübre desteğinin olması çelişki yaratmaktadır (Atış ve Salalı, 2006).

Morishima Teknik İkame Esneklikleri girdiler arası ikame ilişkilerine dair ipuçları sunmaktadır (Çizelge 3). Girdiler arası ikame esnekliklerinin tamamı pozitiftir. $\mathrm{Bu}$, girdiler arasında ikame ilişkisinin olduğu anlamına gelmektedir. Çapraz esneklikler de oldukça yüksek bulunmuştur. Bunun anlamı, herhangi bir girdinin fiyatı arttığında, o girdinin yerine hemen hemen aynı oranda başka bir girdiyle kolayca ikame edilebilmesidir. En yüksek ikame, pestisit ile işgücü arasındadır (1.424). Buna göre pestisit fiyatının $\% 10$ artması, işgücü talebini \%14.24 artırmaktadır. Görüldüğü gibi olası pestisit fiyatı artışlarının, pestisitin kolaylıkla fazladan işgücü kullanımıyla telafi edilmesine yol açmaktadır. Yukarıda da söz edildiği gibi, pestisitten işgücüne geçişin kolay olması, organik kuru üzüm üretimi açısından umut verici bir durumdur. Gübre ve işgücü arasındaki ikame 
esnekliğide yüksek bulunmuştur. Gübre fiyatındaki artışlar, çiftçilerin gübreden vazgeçip işgücü ile bu açığı kapatma eğilimine girmesine yol açmaktadır. Bu durum aynı zamanda, konvansiyonel çekirdeksiz kuru üzüm üreticilerinin organik çekirdeksiz kuru üzüm üretimine daha kolay geçebileceğinin de bir göstergesidir.

Organik kuru üzümle ilgili talebin fiyat esnekliği ve Morishima ikame esneklikleri Çizelge 4'de sunulmuştur. Ana köșegende, yine girdilerin kendi fiyat esneklikleri bulunmaktadır. Organik kuru üzümde girdilerin fiyat esneklikleri konvansiyonel kuru üzümün girdi esneklikleriyle hemen hemen aynıdır. Kuru üzüm çiftçisi konvansiyonel üretimden organik üretime kolayca geçebildiği gibi, girdi fiyatlarındaki gelişmelere göre organik üretimden konvansiyonel üretime dönebilmektedir.

\section{SONUÇ}

Konvansiyonel kuru üzümde, fiyat değişmelerine en duyarlı girdi pestisit; en az duyarlı girdi ise işgücü olarak bulunmuştur. Pestisit ve gübrenin fiyat duyarlılığının yüksek olması, pestisit fiyatlarının farklı politika uygulamalarıyla yüksek tutularak üreticilerin organik kuru üzüm yetiştirmeye teşvik edilmesinin mümkün olabileceğini göstermektedir. Çiftçilerin organik kuru üzümde fiyat değişmelerine karşı en az duyarlı girdi işgücü, en fazla duyarlı girdi ise çekigücüdür. Organik kuru üzüm üretiminde çekigücü fiyat duyarlıı̆̆ının yüksek olması, organik üreticilerin kendilerine

\section{KAYNAKLAR}

Akçay, Y. ve Esengün, K. 2000. Türkiye sekerpancarı üretiminde faktör talep analizi (1980-1998) Translog maliyet fonksiyonu uygulamasi. IV. Ulusal Tarım Ekonomisi Kongresi. 1-6, 6-8 Eylül 2000,Tekirdağ.

Atış, E. ve H.E. Salalı. 2006. AB'de uygulanan tarım-çevre politikalarının Türkiye açısından değerlendirilmesi, Türkiye VII. Tarım Ekonomisi Kongresi (13-15 Eylül 2006, Antalya), Cilt I, s.506-515.

Bayaner, A. 2013. Türkiye Tarımı Beklentiler ve Gelişmeler, Tarımsal Ekonomi ve Politika Geliştirme Enstitüsü, Tepge Yayın No: $224,93 \mathrm{~s}$

Binswanger, H.P. 1974. A cost function approach to the measurement of factor demand and elasticities of substitution, American Journal of Agricultural Economics, 56: 377-386.

Chambers, R.G. 1988. Applied Production Analysis: A Dual Approach. Cambridge, MA: Cambridge University Press.

FAO, 2014. http://faostat.fao.org (Erişim tarihi: 10 Kasım 2014 )

Fuller, F., A.A. Koç., H. Şengul and A. Bayaner. 1999. Farm level feed demand in Turkey. Paper Presented at the American Agricultural Economics Association Annual Meeting, (August 8-11, 1999), Nashville, Tennessee. önerilecek çevre dostu alternatif yenilenebilir enerji ve daha az toprak işleme yöntemlerinin uygulanmasının daha kolay olacağını göstermektedir. Konvansiyonel ve organik kuru üzümde girdi fiyatlarındaki değişmelere üreticiler dikkate değer bir tepki göstermektedir. Buna göre, kuru üzüm üreticisi konvansiyonel üretimden organik üretime kolayca geçebildiği gibi, girdi fiyatlarındaki gelişmelere göre organik üretimden konvansiyonel üretime de geçebilmektedir.

Konvansiyonel ürünlere verilen gübre desteğinin de yeniden gözden geçirilerek organik üretim için bir tersine sübvansiyon etkisi yaratmasının önlenmesi gerekmektedir. Organik tarımsal üretimde kullanılan girdi fiyatlarının yüksek olması nedeniyle üreticilerin bu girdileri kullanması zorlaşmaktadır. Hem küçük üreticilerin bu üretim sistemine geçişi zorlaşmakta hem de organik tarımda sürekliliğin sağlanmasında sorunlar yaşanmaktadır. Üreticilere, organik tarımda kullanılan organik gübre ve ilaçların daha ucuz maliyetle sağlayabilecek politikaların belirlenmesi gerekmektedir. İstikrarlı konvansiyonel ve organik kuru üzüm arzını sağlamak için üreticilere verilen desteklerin yönünün ve şeklinin iyi belirlenmesi şarttır.

\section{TEŞEKKÜR}

Çalışma TÜBITAK tarafından desteklenen TOVAG 110-0-283 no'lu araştırma projesinden elde edilmiştir. Sağlamış olduğu destek için TÜBiTAK'a sonsuz teşekkürlerimizi sunarı.
Huang, K. S. 1991. Factor demands in the U.S. foodmanufacturing industry, American Journal of Agricultural Economics, 73: 615-20.

Kumbasaroğlu, H. ve V. Dağdemir. 2010. Erzurum ilinde buğday, arpa ve çavdarda girdi talebi araştırması, Tarım Bilimleri Dergisi, 16: 194-204.

Laure, B., Y. Dissou, and G.E. West. 1996. Model specification and economies of size in the canadian brewing industry, Review Agricultural Economics, 18: 655-667.

Manisa İGTHM, 2014. Manisa Tarımı - Türkiye İçin Yeri ve Önemi, http://manisa.tarim.gov.tr/Sayfalar/Detay.aspx? SayfaId $=4$, Erişim Tarihi, Temmuz 2015).

Miran, B., C. Abay ve C. Günden. 2002. Pamukta girdi talebi Menemen örneği, Ege Üniversitesi Ziraat Fakültesi Dergisi, 39 (3): 88-95.

Newbold, P. 1995. Statistics For Business and Economics, Prentice Hall International Editions, New Jersey, 867p.

Şener, A. and A. Koç. 1999. Fertiliser Demand in Turkey. Publication, Number:25, Agricultural Research Economic Institute, Ankara, (In Turkish with English Summary), August.

TUIK, 2015. Bitkisel Üretim İstatistikleri, http://www.tuik.gov.tr/ PreTablo.do?alt_id=1001, Erişim Tarihi, Temmuz 2015). 